\title{
MENGENAL SUHU PERMUKAAN LAUT \\ DARI PENGINDERAAN JAUH
}

\author{
Oleh \\ Marindah Yulia Iswari ${ }^{1)}$
}

\begin{abstract}
IDENTIFYING SEA SURFACE TEMPERATURE THROUGH REMOTE SENSING. Sea surface temperature is one of the physical parameters of oceanography that is useful to determine the water quality. Sea surface temperature can be observed using remote sensing technology. Remote sensing sensors must have a thermal infrared or a passive microwave to identify sea surface temperature. NASA's Ocean Color Web have provided sea surface temperature data processed by NASA's Ocean Biology Processing Group (OBPG) team. MODIS and VIIRS are remote sensing instruments used for sea surface temperature data on NASA's Ocean Color Web. The SST data provided in the form of data level 2 and level 3 are processed in daily, weekly, monthly and even yearly.
\end{abstract}

\section{PENDAHULUAN}

Penginderaan jauh ialah ilmu dan seni untuk memperoleh informasi tentang obyek, daerah, atau gejala dengan jalan menganalisis data yang diperoleh dengan menggunakan alat tanpa kontak langsung terhadap obyek, daerah, atau gejala yang dikaji (Lillesand \& Kiefer, 1999). Penginderaan jauh mempunyai dua sistem perekaman yaitu sistem fotografi dan nonfotografi. Penginderaan jauh fotografi menggunakan sensor yang dibawa kamera sehingga menghasilkan data berupa foto udara. Saat ini penginderaan jauh sistem fotografi mulai berkembang lagi dengan adanya wahana pesawat drone. Kelebihan penginderaan jauh sistem fotografi ada pada kedetailan informasinya, namun kelemahannya yaitu pada proses perekamannya yang membutuhkan biaya yang cukup besar. Penginderaan jauh nonfotografi menggunakan wahana satelit dengan sensor yang dibawa oleh satelit tersebut. Penginderaan jauh nonfotografi menghasilkan data berupa citra satelit.

Penginderaan jauh mempunyai 4 konsep resolusi yang meliputi spasial, temporal, spektral dan radiometrik (Danoedoro, 2012). Resolusi spasial merupakan ukuran terkecil obyek yang masih dapat diamati oleh sistem. Semakin kecil ukuran obyek yang dapat teramati maka semakin tinggi dan detail resolusi spasialnya. Citra penginderaan jauh untuk cuaca dan kelautan biasanya mempunyai resolusi spasial yang rendah karena cakupan luasannya yang lebih luas. Satelit sumberdaya kebanyakan menghasilkan citra penginderaan jauh dengan resolusi spasial menengah

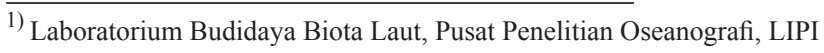


sampai tinggi seperti Landsat (Land Satellite), SPOT (Systeme Probatoire de l'Observation de la Terre) atau ALOS (Advanced Land Observing Satellite). Resolusi temporal berhubungan dengan perekaman ulang pada wilayah yang sama. Satelit mempunyai orbit dan waktu untuk merekam permukaan bumi. Waktu yang dibutuhkan untuk merekam wilayah yang sama pada setiap satelit berbeda-beda. Satelit cuaca dan kelautan umumnya mempunyai resolusi temporal yang tinggi karena sekali perekaman wilayah bumi yang terekam cukup luas. Resolusi spektral merupakan kemampuan sistem untuk membedakan informasi dengan didasari oleh pantulan ataupun pancaran spektral. Setiap satelit dibekali oleh sensor yang sensitif pada panjang gelombang tertentu. Semakin banyak jumlah panjang gelombang yang dikenali maka semakin tinggi kemungkinan sensor tersebut untuk membandingkan obyek berdasarkan pantulannya. Resolusi radiometrik dapat diartikan sebagai kemampuan sensor dalam mencatat respons spektral obyek. Respons spektral ini dikoding (digital coding) dan dinyatakan dalam bentuk bit.

Salah satu kelebihan penginderaan jauh adalah melakukan analisis pada area yang luas sekaligus dalam satu waktu (Reif, 2011). Kemampuannya dalam temporal, penginderaan jauh mempunyai data time series yaitu melakukan perekaman pada wilayah yang sama dalam jangka waktu tertentu. Sebagai contoh, satelit Landsat 8 OLI (Land Satellite sensor OLI) mempunyai resolusi temporal 16 hari sehingga daerah yang sama akan direkam setiap 16 hari sekali. Satelit cuaca mempunyai resolusi temporal yang lebih tinggi seperti NOAA (National Oceanic and Atmospheric Administration) yang merekam bumi 2 kali dalam 24 jam. Kelebihan-kelebihan ini yang menjadikan penginderaan jauh sering digunakan untuk bidang kelautan.

Dua pertiga bagian bumi merupakan perairan yang mempunyai sifat dinamis. Monitoring wilayah perairan yang dinamis ini membutuhkan waktu yang lama dan biaya yang besar. Penginderaan jauh dapat membantu dalam melakukan kegiatan monitoring perairan laut dengan didukung oleh data real timel in situ untuk validasi dan akurasi. Dalam memonitoring kualitas perairan, penginderaan jauh mempunyai beberapa keunggulan (Reif, 2011) :

1. Kemampuan synoptic view lebih efektif dalam monitoring secara spasial dan temporal,

2. Menampilkan informasi kualitas perairan dalam satu waktu pada area yang luas sekaligus,

3. Menampilkan perekaman secara temporal dari masa lampau sampai sekarang,

4. Alat untuk mencari lokasi dan waktu yang tepat dalam survei dan pengambilan sampel, dan

5. Memperkirakan parameter-parameter penciri kualitas perairan.

\section{SUHU PERMUKAAN LAUT}

Suhu permukaan (surface temperature) didefinisikan sebagai suhu 
antarmuka permukaan bumi dan atmosfer (Fawzi, 2016). Variasi suhu harian permukaan benda dipengaruhi oleh sifat termal tersebut. Suhu permukaan laut adalah parameter iklim dan cuaca yang dapat diukur secara harian dengan gelombang inframerah pada satelit, gelombang mikro pasif, pengukuran in situ dengan mooring/ pemasangan buoy dan pengukuran langsung dengan perahu (Gentemann, 2011). Penginderaan jauh dapat mengidentifikasi suhu permukaan laut jika sensor yang dibawa oleh satelit mempunyai gelombang inframerah termal atau gelombang mikro pasif. Inframerah termal atau thermal infrared (TIR) sudah digunakan lebih dari 40 tahun untuk dioperasikan pada satelit meteorologi. Pada kondisi banyak awan maka TIR digunakan sebagai monitor temperatur awan, sedangkan pada kondisi tidak ada awan TIR digunakan untuk mengobservasi pola suhu permukaan laut (Purkis \& Klemas, 2011).

Suhu permukaan laut dipengaruhi oleh faktor fisik seperti panas matahari, arus permukaan, keadaan awan, upwelling, divergensi dan konvergensi pada daerah muara dan garis pantai (Hela \& Laevastu, dalam Limbong, 2008). Faktor meteorologi juga ikut berpengaruh terhadap suhu permukaan laut seperti curah hujan, penguapan, kelembaban udara, suhu udara, kecepatan angin dan intensitas radiasi matahari (Arief et al., 2015). Secara global, suhu permukaan laut dibutuhkan untuk memonitoring kerusakan terumbu karang (Purkis \& Klemas, 2011). Salah satu penelitian yang mengkaji analisis hubungan suhu permukaan laut dan pemutihan karang dilakukan oleh (Wouthuyzen et al., 2015). Suhu permukaan laut yang digunakan berasal dari citra penginderaan jauh yaitu hasil perekaman Terra MODIS dan Aqua MODIS. Integrasi suhu permukaan laut dan klorofil-a dapat digunakan untuk memprediksi daerah tangkapan ikan. Penelitian Tangke et al. (2015) menyimpulkan bahwa sebaran parameter oseanografi berupa suhu permukaan laut dan klorofil-a di Laut Halmahera mempengaruhi hasil tangkapan yellowfin tuna dengan koefisien determinasi 0.29 dan 4.78 .

\section{PRODUK OCEAN COLOR}

Ocean color (https://oceancolor. gsfc.nasa.gov) merupakan salah satu website yang dikelola NASA untuk menghasilkan produk-produk ocean color melalui penginderaan jauh. Tim NASA's Ocean Biology Processing Group (OBPG) membantu untuk mengkoleksi, memproses, kalibrasi, validasi, menyimpan dan mendistribusikan produk yang berkaitan dengan laut. Produk-produk tersebut difasilitasi oleh NASA Ocean Data Processing System (ODPS) yang telah berkecimpung dalam penggunaan data penginderaan jauh sejak 1996. NASA menyiapkan data penginderaan jauh yang digunakan sebagai sumber data spasial untuk ocean color. Instrumen-instrumen yang digunakan oleh NASA untuk ocean color meliputi Aquaris, CZCS (The Coastal Zone Color Scanner Experiment), GOCI (The Geostationary Ocean Color 
Imagery), HICO (The Hyperspectral Imager for the Coastal Ocean), MERIS (The Medium Resolution Imaging Spectrometer), MODIS Aqua (Moderate Resolution Imaging Spectrometer Aqua), MODIS Terra (Moderate Resolution Imaging Spectrometer Terra), OCTS (Ocean Color and Temperature Scanner), OLCI-53A (The Ocean and Land Colour Instrument 53A), PACE (The Plankton, Aerosol, Cloud, and Ocean Ecosystem), SeaWiffS (Sea-Viewing Wide Field-ofView Sensor), VIRRS-SNPP (The Visible and Infrared Imager/Radiometer Suite SNPP).

Salah satu produk ocean color adalah Standard Sea Surface Temperature Products. Produk yang dihasilkan ada dua macam yaitu SST (Sea Surface Temperature) dan SST4 (Sea Surface Temperature4). Produk suhu yang diperoleh dari penginderaan jauh sebagian besar membutuhkan gelombang termal untuk mendeteksinya walaupun terdapat beberapa kasus bahwa gelombang inframerah dekat juga mampu melihat lokasi kebakaran hutan (Fawzi, 2016). Produk SST berasal dari gelombang panjang $(11-12 \mu \mathrm{m})$ pada radiasi termal, sedangkan SST4 berasal dari gelombang pendek $(3-4 \mu \mathrm{m})$ pada radiasi termal.

Saat ini data suhu permukaan laut pada pranala ocean color dihasilkan oleh MODIS dan VIIRS. Algoritma-algoritma yang dibangun lebih diprioritaskan untuk diaplikasikan terhadap MODIS, karena MODIS lebih dulu diluncurkan dibandingkan VIIRS. Algoritma yang sudah pernah dibangun untuk MODIS, kemudian diaplikasikan ke VIIRS. Meskipun VIIRS masih tergolong sensor yang baru saja diluncurkan, VIIRS sudah menghasilkan produk SST pada pranala ocean color dalam level 2 dan level 3.

\section{SENSOR MODIS (MODERATE RESOLUTION IMAGING SPECTROMETER)}

MODIS (Moderate Resolution
Imaging Spectrometer) merupakan Imaging Spectrometer) merupakan melintang gerak orbit (across-track scanning) (Danoedoro, 2012). Sensor MODIS diusung oleh dua satelit yaitu Terra dan Aqua. Sensor ini digunakan untuk tujuan pengukuran sifat fisik atmosfer, daratan dan lautan. Jarak satelit dengan permukaan bumi adalah $705 \mathrm{~km}$ dengan area perekaman 2330 $\mathrm{km}$. Satelit Terra mempunyai orbit dari utara ke selatan bumi (descending pass), dan merekam pada pukul 10.30. Satelit Aqua merekam pada pukul 13.30 dengan orbit dari selatan ke utara bumi (ascending pass) (Hosida et al., 2007). MODIS dirancang untuk membangun rekaman data secara berkelanjutan, seperti AVHRR NOAA tahun 1979. Keunggulan MODIS dalam resolusi spasial, kepekaan radiometri, retrifikasi geometri serta kalibrasi radiometri lebih kuat dibandingkan dengan AVHRR NOAA (Aronoff, 2005).

MODIS Terra dan Aqua diluncurkan pada 18 Desember 1999 dan 04 Mei 2002. MODIS mempunyai kelebihan untuk menghasilkan data multi 
temporal dengan panjang gelombang yang lebar yaitu dari gelombang tampak sampai infamerah jauh (Xiong et al. 2009). Secara keseluruhan MODIS mempunyai 36 saluran spekral dengan rentang 0.405-14.385 $\mu \mathrm{m}$. Resolusi spasial MODIS bervariasi mulai dari 250, 500 dan 1000m (Tabel 1).

Tabel 1. Spesifikasi spektral pada MODIS (Lindsey et al., 2000)

\begin{tabular}{|c|c|c|}
\hline Band & Bandwith (nm) & Primary Use \\
\hline 1 & $620-670$ & \multirow{2}{*}{ Land/Cloud Boundaries } \\
\hline 2 & $841-876$ & \\
\hline 3 & $459-479$ & \multirow{5}{*}{ Land/Cloud Properties } \\
\hline 4 & $545-565$ & \\
\hline 5 & $1230-1250$ & \\
\hline 6 & $1628-1652$ & \\
\hline 7 & $2105-2155$ & \\
\hline 8 & $405-420$ & \multirow{9}{*}{ Ocean Color/Phytoplankton/Biogeochemistry } \\
\hline 9 & $438-448$ & \\
\hline 10 & $483-493$ & \\
\hline 11 & $526-536$ & \\
\hline 12 & $546-556$ & \\
\hline 13 & $662-672$ & \\
\hline 14 & $673-683$ & \\
\hline 15 & $743-753$ & \\
\hline 16 & $862-877$ & \\
\hline 17 & $890-920$ & \multirow{3}{*}{ Atmospheric Water Vapor } \\
\hline 18 & $931-941$ & \\
\hline 19 & $915-965$ & \\
\hline Band & Bandwith $(\mu \mathrm{m})$ & Primary Use \\
\hline 20 & $3.660-3.840$ & \multirow{4}{*}{ Surface/Cloud Temperature } \\
\hline 21 & 3.929-3.989 & \\
\hline 22 & 3.929-3.989 & \\
\hline 23 & $4.020-4.080$ & \\
\hline 24 & 4.433-4.498 & \multirow{2}{*}{ Atmospheric Temperature } \\
\hline 25 & 4.482-4.549 & \\
\hline
\end{tabular}




\begin{tabular}{|c|c|c|}
\hline 26 & $1.360-1.390$ & Cirrus Clouds \\
\hline 27 & $6.535-6.895$ & \multirow{2}{*}{ Water Vapor } \\
\hline 28 & $7.175-7.475$ & \\
\hline 29 & $8.400-8.700$ & Ozone \\
\hline 30 & $9.580-9.880$ & Surface/Cloud Temperature \\
\hline 31 & $10.780-11.280$ & \\
\hline 32 & $13.185-13.485$ & Cloud Top Altitude \\
\hline 33 & $13.185-13.485$ & \\
\hline 34 & $13.485-13.785$ & \\
\hline 35 & $13.785-14.085$ & \\
\hline 36 & $14.085-14.385$ & \\
\hline
\end{tabular}

SENSOR VIIRS (VISIBLE

INFRARED IMAGING

RADIOMETER SUITE)

VIIRS merupakan sensor yang pertama kali diluncurkan pada SuomiNPP pada 28 Oktober 2011. Suomi-NPP mempunyai lintasan orbit yang sama dengan Terra MODIS, tetapi mengorbit di atas ketinggian Terra MODIS (Seaman, 2013). VIIRS mempunyai 22 saluran spektral dengan panjang gelombang antara 0.4 sampai $12.0 \mu \mathrm{m}$ (Lei et al. 2012). Saluran pada VIIRS dibagi menjadi 3 bagian sesuai dengan resolusi spasialnya (Tabel 2). Saluran low-light Day-Night hanya ada 1 buah dengan resolusi spasial $750 \mathrm{~m}$. Saluran dengan resolusi menengah $(750 \mathrm{~m})$ berjumlah 16 buah dengan penamaan Moderate (M), sedangkan saluran dengan resolusi lebih tinggi $(375 \mathrm{~m})$ berjumlah 5 buah dengan penamaan Imagery (I).

Tabel 2. Spesifikasi Saluran di sensor VIIRS (Cao et al., 2013)

\begin{tabular}{|c|c|c|}
\hline Band & Wavelength $(\mu \mathrm{m})$ & Application \\
\hline M1 & 0.412 & Ocean Color/Aerosol \\
\hline M2 & 0.445 & Ocean Color/Aerosol \\
\hline M3 & 0.488 & Ocean Color/Aerosol \\
\hline M4 & 0.555 & Ocean Color/Aerosol \\
\hline I1 & 0.64 & Imagery \\
\hline M5 & 0.72 & Ocean Color/Aerosol \\
\hline M6 & 0.746 & Atmospheric Correction \\
\hline I2 & 0.865 & NDVI \\
\hline M7 & 0.865 & Ocean Color/Aerosol \\
\hline
\end{tabular}




\begin{tabular}{|c|c|c|}
\hline DNB & 0.7 & Imagery \\
\hline M8 & 1.24 & Cloud Particle Size \\
\hline M9 & 1.378 & Cirrus/Cloud Cover \\
\hline I3 & 1.61 & Binary Snow Map \\
\hline M10 & 1.61 & Snow Fraction \\
\hline M11 & 2.25 & Clouds \\
\hline I4 & 3.74 & Imagery Clouds \\
\hline M12 & 3.7 & SST \\
\hline M13 & 4.05 & SST/ Fires \\
\hline M14 & 8.55 & Cloud Top Properties \\
\hline M15 & 10.763 & SST \\
\hline I5 & 11.45 & Cloud Imagery \\
\hline M16 & 12.013 & SST \\
\hline
\end{tabular}

VIRRS akan memberikan kemampuan untuk memproduksi resolusi yang lebih tinggi terutama resolusi spektral dan radiometrik. Perubahan secara global dapat dipantau dengan VIIRS, karena sensornya membawa panjang gelombang yang berguna untuk monitoring darat, laut, awan dan atmosfer. Salah satu kegunaan VIIRS untuk bidang kelautan meliputi monitoring suhu permukaan laut, prediksi badai, informasi cuaca, perubahan iklim ataupun asimilasi ke dalam model sirkulasi laut (Zhou, 2011). Produk SST yang diperoleh dari VIRRS dan AVHRR (Advanced Very High Resolution Radiometer) mengkombinasikan nilai suhu permukaan laut yang diterima oleh sensor satelit dengan suhu pada pengukuran lapangan (Martin, 2014).

\section{DATA LEVEL 2 DAN LEVEL 3}

\begin{tabular}{lcr}
\multicolumn{2}{c}{ Perkembangan } & \multicolumn{2}{c}{ penginderaan } \\
jauh semakin pesat dengan adanya \\
pengembangan & algoritma untuk
\end{tabular}

kebutuhan analisis citra. Salah satu algoritma yang sudah dikembangkan oleh ocean color adalah algoritma untuk suhu permukaan laut. Algoritma suhu permukaan laut kemudian diaplikasikan pada citra penginderaan jauh sehingga menghasilkan data suhu permukaan laut dalam cakupan spasial. Data-data tersebut sudah diolah dan dapat diunduh secara gratis melalui pranala ocean color. Pengolahan data suhu permukaan laut dalam cakupan spasial ini merupakan salah satu pekerjaan dari tim OBPG dari NASA. Wilayah spasial yang dimaksudkan mencakup seluruh dunia yang dibagi menjadi beberapa zona grid atau scene citra. Data citra yang sudah diolah ini dimasukkan dalam data level 2 dan level 3 dan dapat digunakan sesuai kebutuhan pengguna/ user.

Analisis suhu permukaan laut dari sensor MODIS telah dilakukan dengan menggunakan perangkat lunak yang dikembangkan oleh Rosenstiel School of Marine and Atmospheric 
Science (RSMAS) di University of Miami. Perangkat lunak dari RSMAS ini diberi nama "PGE10" atau "modsst". Saat ini pengolahan dan distribusi produk suhu permukaan laut dari MODIS, dilakukan oleh tim OBPG yang bekerja di bawah NASA. OBPG menggunakan perangkat lunak Multi-Sensor Level-1 to Level-2 atau "msl12" untuk menghasilkan konversi MODIS menjadi SPL. OBPG bertugas untuk menterjemahkan datadata yang lama dari "modsst" untuk diolah dengan perangkat lunak "msl12" (Franz, 2006).

Algoritma produk SST (Sea Surface Temperature) dan SST4 (Sea Surface Temperature4) diperoleh dari panjang gelombang yang berbeda. Algoritma SST menggunakan gelombang panjang yaitu saluran 31 dan $32(11 \mu \mathrm{m}$ dan $12 \mu \mathrm{m})$ pada MODIS. Temperatur kecerahan produk SST diperoleh dengan inversi linier hubungan antara radian dan temperatur benda hitam, sedangkan temperatur kecerahan produk
SST4 menggunakan inversi logaritma hubungan antara radian dan temperatur benda hitam. Gelombang yang digunakan oleh algoritma produk SST4 berasal dari gelombang pendek yaitu saluran 22 dan $23(3.959 \mu \mathrm{m}$ dan $4.050 \mu \mathrm{m})$ pada MODIS (Franz, 2005).

Produk SST yang diperoleh dari sensor MODIS dan VIIRS menghilangkan nilai radian atmosfer sehingga nilai suhu permukaan laut harus dikalibrasi dengan observasi in situ. Validasi produk SST (Sea Surface Temperature) menggunakan data yang berasal dari radiometer inframerah yang dipasang pada kapal dengan akurasi yang tinggi. Selain itu, validasi diperoleh dari buoy yang mengapung atau tertambat pada kedalaman 1 meter atau lebih yang tersebar di seluruh perairan dunia (Gambar 1). Nilai radiometrik suhu permukaan laut pada permukaan perairan disediakan oleh Marine Atmospheric Emitted Radiance Interferometer (M-AERI) (Minnett et al., 2004). 


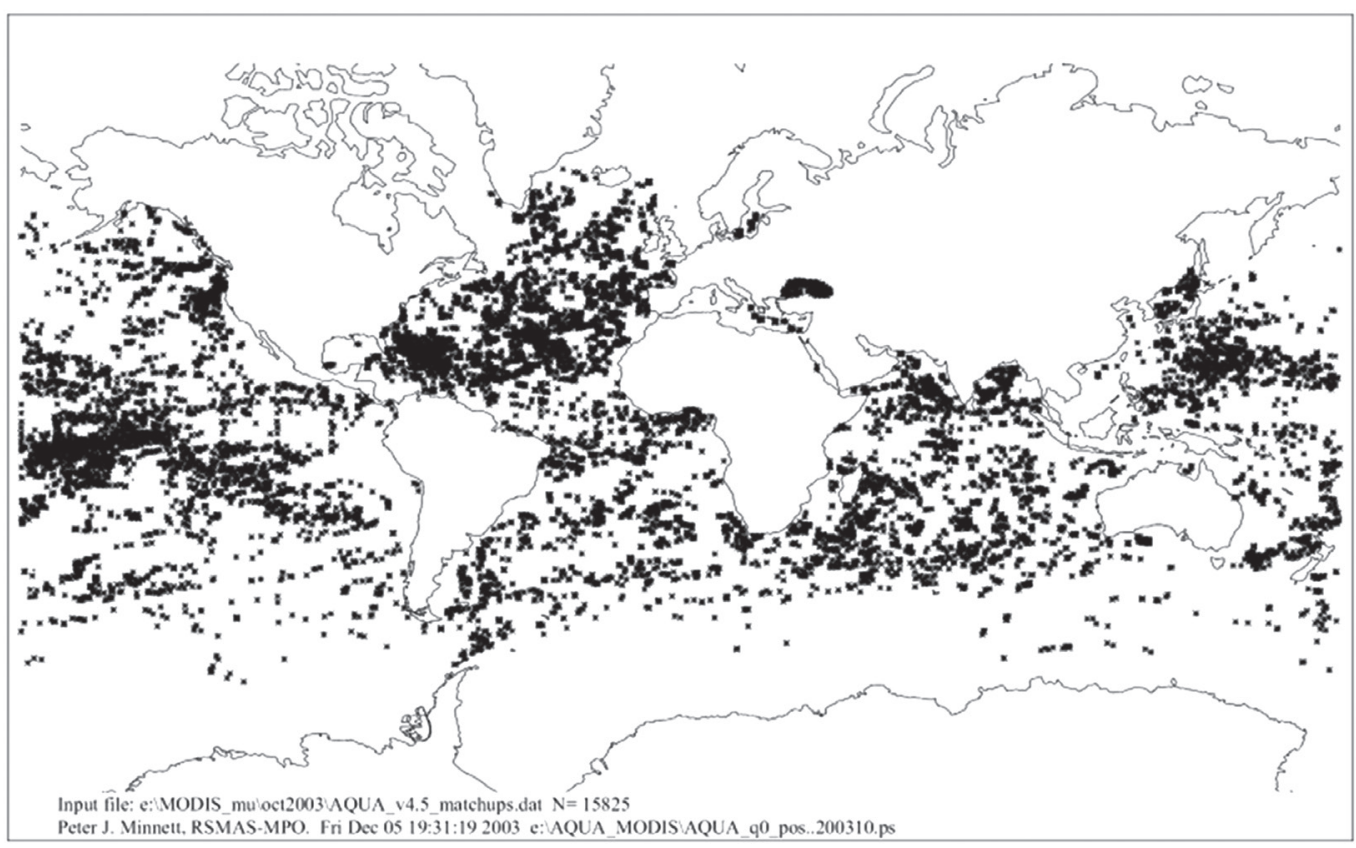

Gambar 1. Titik pemasangan buoy untuk validasi data Aqua MODIS (Minnett et al., 2004)

Produk level 2 memuat beberapa variabel geofisik yang mempunyai resolusi spasial sama dengan level 1 . Data pada level 2 sudah dikonversi oleh OBPG dan menghasilkan nilai suhu dalam satuan derajat celcius $\left({ }^{\circ} \mathrm{C}\right)$. Produk ini masih memerlukan koreksi yaitu koreksi geometrik, karena raw data hasil unduhan masih belum terproyeksikan. Proyeksi dilakukan untuk mendapatkan posisi yang sesuai dengan kondisi sebenarnya. Pengolahan proyeksi untuk produk SST menggunakan perangkat lunak untuk pengolahan citra. Citra sebelum dan setelah diproyeksikan dapat di lihat pada Gambar 2 untuk Terra MODIS, Gambar 3 untuk Aqua MODIS dan Gambar 4 untuk IIRS.
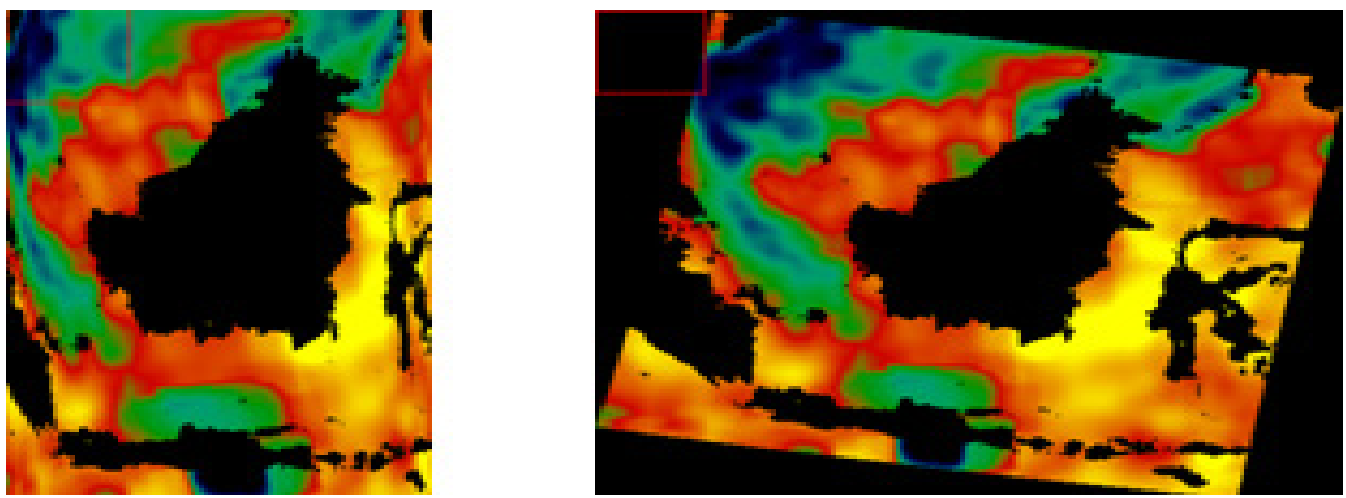

Gambar 2. Produk SST pada Terra MODIS Level 2 sebelum diproyeksikan dan setelah diproyeksikan (pengolahan data: Iswari, 2017). 

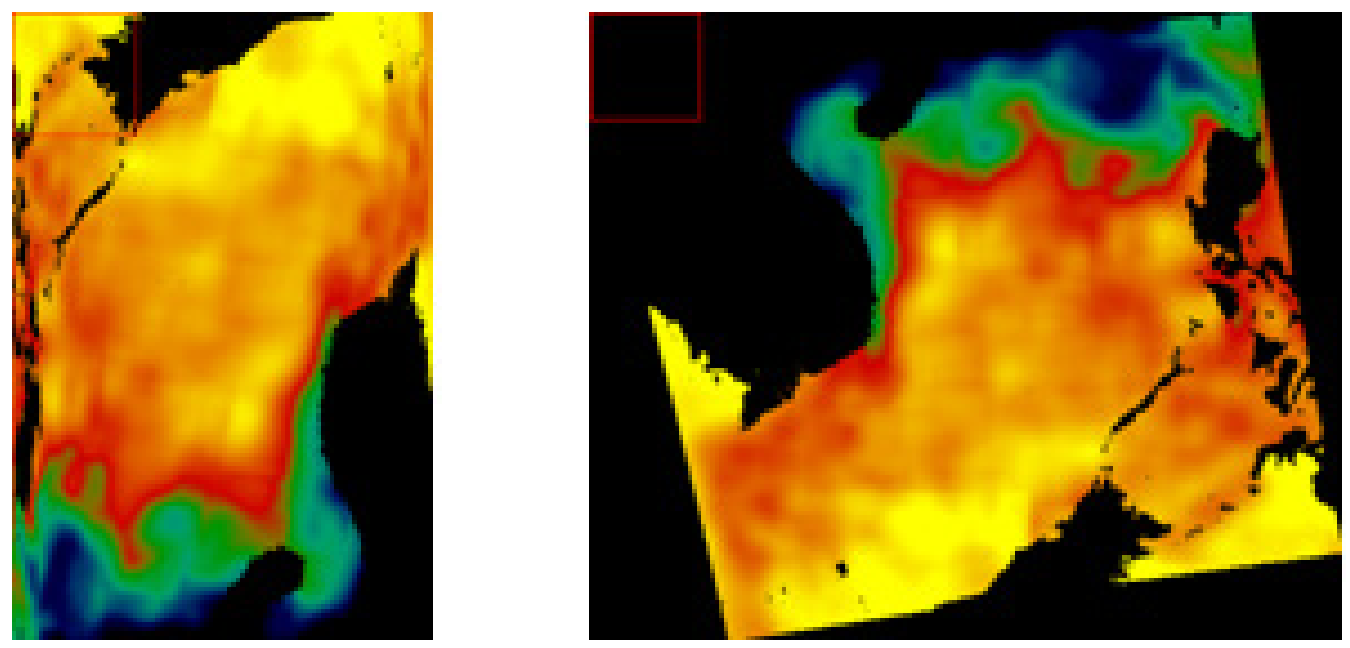

Gambar 3. Produk SST pada Aqua MODIS Level 2 sebelum diproyeksikan dan setelah diproyeksikan (pengolahan data: Iswari, 2017)
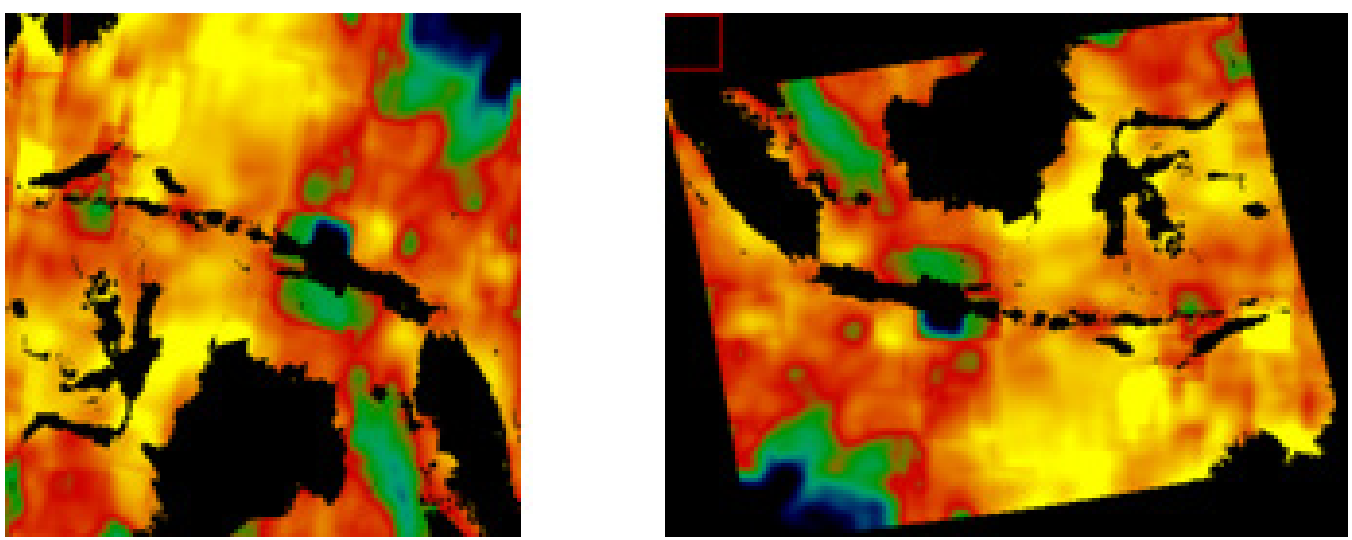

Gambar 4. Produk SST pada VIIRS Level 2 sebelum diproyeksikan dan setelah diproyeksikan (pengolahan data: Iswari, 2017).

Satelit penginderaan jauh jauh, tanpa harus membuka metadata menghasilkan citra penginderaan jauh pada setiap waktu perekaman. Format penamaan citra penginderaan jauh biasanya dibedakan berdasarkan jenis sensor, dan tanggal perekaman. Hal ini memudahkan pengguna untuk mengidentifikasi file citra penginderaan dari citra tersebut. Penamaan produk ocean color pada level 2 adalah iyyyydddh mmss.L2_ttt_ppp.nc dengan penjelasan seperti yang tertuang pada Tabel 3. 
Tabel 3. Penamaan produk Ocean Color pada level 2

\begin{tabular}{|l|l|}
\hline $\mathbf{i}$ & $\begin{array}{l}\text { instrument (S untuk SeaWiFS, A untuk Aqua MODIS, T untuk } \\
\text { Terra MODIS, O untuk OCTS, C untuk CZCS, M untuk MERIS, } \\
\text { V untuk VIIRS, H untuk HICO) }\end{array}$ \\
\hline yyyydddhhmmss & $\begin{array}{l}\text { untuk tahun, hari ke berapa dalam satu tahun, jam, menit, detik } \\
\text { perekaman }\end{array}$ \\
\hline $\mathbf{t t t}$ & data opsional \\
\hline $\mathbf{p p p}$ & $\begin{array}{l}\text { untuk produk yang dihasilkan (OC untuk Ocean Color, SST untuk } \\
\text { suhu permukaan laut, IOP untuk Inherent Optical Properties) }\end{array}$ \\
\hline .nc & format data NetCDF (Network Common Data Format) \\
\hline
\end{tabular}

Produk SST pada level 2 diproduksi setiap hari dengan perekaman siang hari atau malam hari. Kompilasi produk level 2 digunakan untuk pembuatan grid pada level 3. Produk level 3 hasil grid dari produk level 2 meliputi data harian, mingguan, bulanan bahkan data tahunan dengan kondisi pada siang hari dan malam hari. Data level 2 dan level 3 menghasilkan suhu permukaan laut pada resolusi $1 \mathrm{~km}$ (level 2) dan $4.6 \mathrm{~km}, 36 \mathrm{~km}$ dan $1^{\circ}$ (level 3) dalam status perairan global (NASA, 2000).

Data pada level 3 berasal dari variabel geofisik yang sudah terproyeksi dalam grid-grid spasial dan temporal. Produk level 3 ini dibagi menjadi data binned dan data SMI (Standard Mapped Image). Data binned ini memuat data yang berasal dari akumulasi semua data pada level 2. Setiap data binned di level 3 disimpan dalam satu atau lebih format HDF. Data SMI pada level 3 merepresentasikan dari data binned yang diperoleh dari SeaWIFS, MODIS, OCTS atau CZCS. Setiap produk SMI mempunyai atribut global dan ditampilkan dalam proyeksi Equidistant Cylindrical (Plate Carre) seperti pada gambar 5 untuk Terra MODIS, Gambar 6 untuk Aqua MODIS dan Gambar 7 untuk VIIRS. Nilai yang ditunjukan oleh produk SMI disimpan dalam bentuk byte, 2 byte data integer dan 4 byte data float.

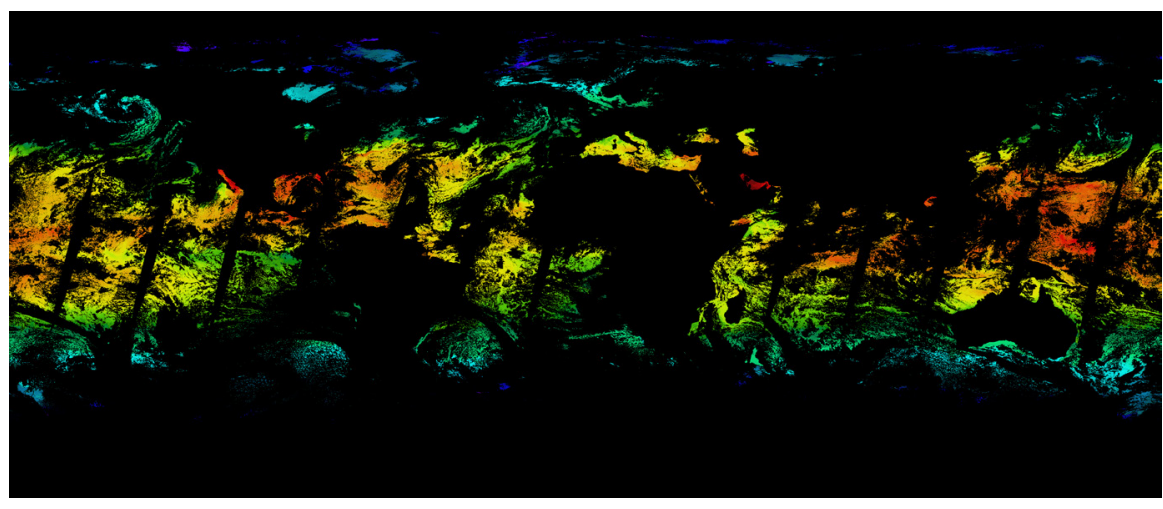

Gambar 5. Terra MODIS Level 3 (Standard Mapped Image Product 4km) (sumber : https://oceancolor.gsfc.nasa.gov/cgi/l3) 


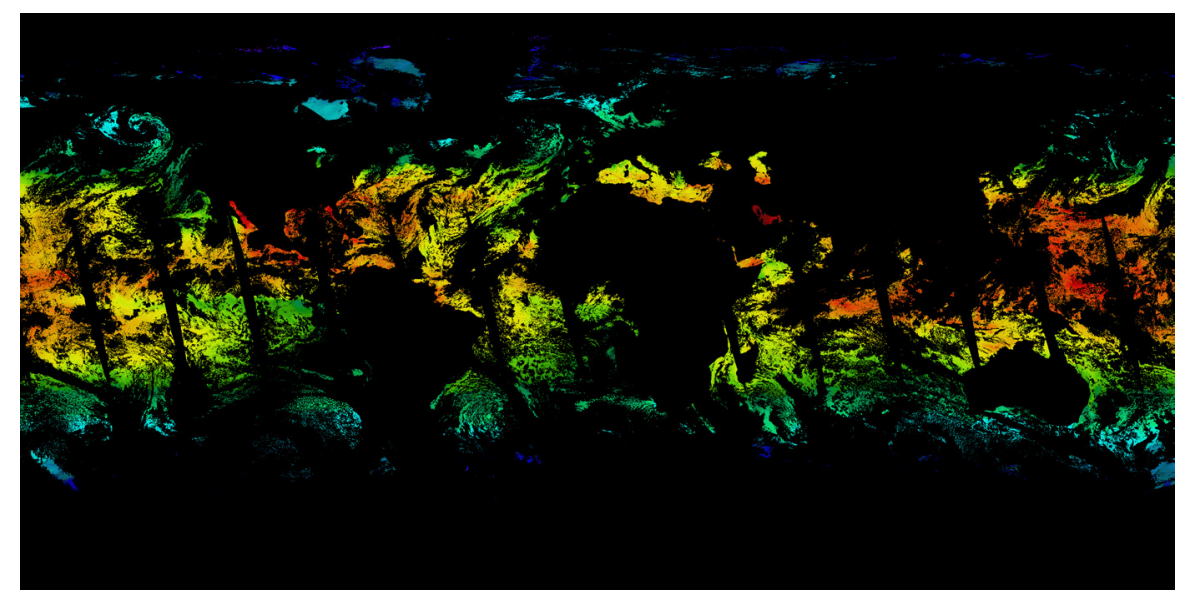

Gambar 6. Aqua MODIS Level 3 (Standard Mapped Image Product 4km) (sumber : https://oceancolor.gsfc.nasa.gov/cgi/13)

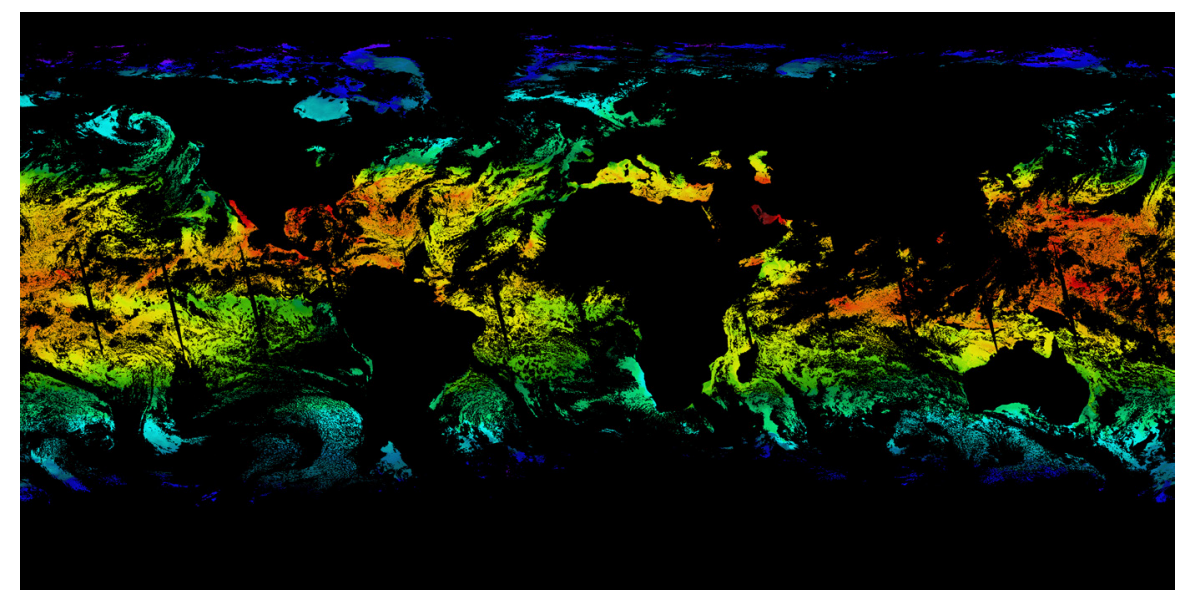

Gambar 7. VIIRS Level 3 (Standard Mapped Image Product 4km) (sumber : https://oceancolor.gsfc.nasa.gov/cgi/13)

\section{PENUTUP}

Perkembangan sistem penginderaan jauh diikuti dengan pengembangan terhadap aplikasinya sebagai contoh di bidang kelautan. Salah satu pemanfaatan penginderaan jauh untuk kelautan, yaitu perolehan suhu permukaan laut. Pranala ocean color (https://oceancolor. gsfc.nasa.gov) sampai saat ini sudah menyediakan data suhu permukaan laut dari penginderaan jauh dengan variasi level 2 dan level 3. Pengolahan data di pranala ocean color dilakukan oleh tim NASA's Ocean Biology Processing Group (OBPG) dengan memanfaatkan dua instrumen yaitu MODIS (Moderate Resolution Imaging Spectrometer) dan VIIRS (Visible Infrared Imaging 
Radiometer Suite). Data suhu permukaan laut dapat diunduh secara harian bahkan tahunan. Data dari pranala ocean color ini sudah di validasi menggunakan data yang berasal dari radiometer inframerah dan buoy yang tersebar di seluruh perairan dunia.

\section{DAFTAR PUSTAKA}

Arief, M. S. W. Adawiyah, E. Parwati, R. Hamzah, and T. Prayogo. 2015. Pengembangan model ekstraksi suhu permukaan laut menggunakan data satelit Landsat 8, Studi kasus : Teluk Lampung. Jurnal Penginderaan Jauh 12 (2): 107-122.

Aronoff, S. 2005. Remote Sensing for GIS Managers. ESRI Press, U.S : $524 \mathrm{p}$

Cao, C., X. Xiong, R. Wolfe, F. DeLuccia, Q. Liu, S. Blonski, and G. Lin. 2013. "NOAA Technical Report NESDIS 142 Visible Infrared Imaging Radiometer Suite (VIIRS) Sensor Data Record (SDR) User's Guide". Washington, D.C : U.S. Department of Commerce, NOAA

Danoedoro, P. 2012. Pengantar penginderaan jauh digital. Edited by Benedicta Rini W. I. Penerbit Andi Offset, Yogyakarta : 398 hlm.
Fawzi, N. 2016. Penginderaan jauh untuk lingkungan dan konservasi. Penerbit Ombak, Yogyakarta: $286 \mathrm{hlm}$.

Franz, B. 2005. "MODIS SST Processing and support for GHRSST at OBPG." Greenbelt : Goddart Space Flight Center, NASA .

Franz, B. 2006. Transition of MODIS SST Processing to the OBPG. https://oceancolor.gsfc.nasa. gov/docs/modis_sst/sst_ transition/ diakses pada tanggal 8 Agustus 2017.

Gentemann, C. L. 2011. Sea Surface Temperature: Satellite Microwave SSTs for climate. In WCRP OSC, climate Research in Service to Society.

Hosida, K. H. Murakami, F. Sakaida, and H. Kawamura. 2007. Algorithm and validation of Sea Surface Temperature observation using MODIS Sensors Aboard Terra and Aqua in the Western North Pacific. Journal of Oceanography 63: 267-280.

Lei, N., Z. Wang, B. Guenther, X. Xiong, and J. Gleason. 2012. Modeling the detector radiometric response gains of the suomi NPP VIIRS Reflective Solar Bands. Sensors, Systems, and Next-Generation Satellites XVI 8533: 1-11. 
Lillesand, T. M. and R. W Kiefer. 2000. Remote Sensing and Image Interpretation. 4th ed. John Wiley \& Sons : 736 p.

Limbong, M. 2008. Pengaruh suhu permukaan laut terhadap jumlah dan ukuran hasil tangkapan ikan Cakalang di perairan Teluk Palabuhanratu Jawa Barat. Bogor : Institut Pertanian Bogor.

Lindsey, R. D. Herring, M. Abbott, B. Conboy, W. Esaias, C. Justice, M. King, B. Murphy, and V. Salomonson. 2000. MODIS (Moderate-Resolution Imaging Spectrotradiometer). Greenbelt, Maryland : NASA.

Martin, S. 2014. An Introduction to Ocean Remote Sensing. 2nd ed. Cambridge University Press, New York : 521p.

Minnett, P. J., O. B Brown, R. H. Evans, E. L. Key, E. J. Kearns, K. Kilpatrick, A. Kumar, K. A. Maillet, and G. Szczodrak. 2004. Sea-Surface Temperature Measurements from the Moderate-Resolution Imaging Spectroradiometer (MODIS) on Aqua and Terra. In 2004 IEEE International Geoscience and Remote Sensing Symposium Proceedings, 7:4576-4579.

NASA, National Aeronautics Space Administration. 2000. EOS Data Products Handbook
Volume 2. Edited by Claire L. Parkinson and Reynold Greenstone. Vol. 2. Greenbelt: NASA Goddard Space Flight Center.

Purkis, S. and V. Klemas. 2011. Remote sensing and global environmental change. 1st ed. Wiley-Blackwell, West Sussex, UK : 384p.

Reif, M. 2011. Remote Sensing for inland water quality monitoring: A U.S. Army Corps of Engineers Perspective. Kiln : Joint Airborne Lidar Bathymetry Technical Center of eXpertise.

Seaman, C. 2013. Beginner' S Guide to VIIRS Imagery Data VIIRS Intro. Colorado State University.

Tangke, U. J. C. Karuwal, M. Zainuddin, and A. Mallawa. 2015. Sebaran suhu permukaan laut dan klorofil-a pengaruhnya terhadap hasil tangkapan Yellowfin Tuna (Thunnus Albacares) di perairan laut Halmahera bagian Selatan. Jurnal IPTEKS PSP 2 (April): 248-260.

Wouthuyzen, S. M. Abrar, and J. Lorwens. 2015. Pengungkapan kejadian pemutihan karang tahun 2010 di Perairan Indonesia melalui analisis suhu permukaan laut. Jurnal Oseanologi Dan Limnologi 1(Desember): 305327. 
Xiong, X, K. Chiang, J. Sun, W. L Barnes, B. Guenther, and V. V Salomonson. 2009. NASA EOS Terra and Aqua MODIS onOrbit performance. Advances in Space Research 43 (3). COSPAR: 413-422.
Zhou, L. 2011. Advances in Imagers from AVHRR to VIIRS. Joint Polar Satellite System (JPSS), Miami. 